\title{
Design a Monitoring and Control in Irrigation Systems using Arduino Wemos with the Internet of Things
}

Lukman Medriavin Silalahi, Setiyo Budiyanto*, Freddy Artadima Silaban, Arif Rahman Hakim Department of Electrical Engineering, Faculty of Engineering, Universitas Mercu Buana, Indonesia

\begin{abstract}
Irrigation door is a big issue for farmers. The factor that became a hot issue at the irrigation gate was the irresponsible attitude of the irrigation staff regarding the schedule of opening/closing the irrigation door so that it caused the rice fields to becoming dry or submerged. In this research, an automatic prototype system for irrigation system will be designed based on integrating several sensors, including water level sensors, soil moisture sensors, acidity sensors. This sensor output will be displayed on Android-based applications. The integration of communication between devices (Arduino Nano, Arduino Wemos and sensors supporting the irrigation system) is the working principle of this prototype. This device will control via an Android-based application to turn on / off the water pump, to open/close the irrigation door, check soil moisture, soil acidity in real time. The pump will automatically turn on based on the water level. This condition will be active if the water level is below $3 \mathrm{~cm}$ above ground level. The output value will be displayed on the Android-based application screen and LCD screen. Based on the results of testing and analysis of the prototype that has been done in this research, the irrigation door will open automatically when the soil is dry. This condition occurs if the water level is less than $3 \mathrm{~cm}$. The calibrated Output value, including acidity sensor, soil moisture sensor and water level sensor, will be sent to the server every 5 seconds and forwarded to an Android-based application as an output display.
\end{abstract}

\author{
Keywords: \\ Arduino Wemos; \\ Control; \\ Internet of Things; \\ Monitoring; \\ Smart Irrigation; \\ Article History: \\ Received: April 9, 2021 \\ Revised: June 20, 2021 \\ Accepted: June 22, 2021 \\ Published: June 26, 2021 \\ Corresponding Author: \\ Setiyo Budiyanto \\ Electrical Engineering Department. \\ Universitas Mercu Buana, \\ Indonesia \\ Email: \\ sbudiyanto@mercubuana.ac.id
}

\section{INTRODUCTION}

An irrigation gate is one of the main factors regulating water discharge in an area by looking at current conditions where weather conditions are unpredictable [1][2]. For example, sometimes rain and wind storms quickly and simultaneously, resulting in increased water discharge in the river. Therefore, it is very important to have a water gate that can open, regulate and close the flow of water that can work at any time quickly with the movement of opening, regulating and closing itself automatically. So, the water flow in the area can be controlled [2][3].

Irrigation is an effort to bring in water by designing irrigation canals to go to the fields or fields regularly and disposing of water that is no longer needed $[4,5,6]$. Rice fields/gardens need water flow, and water flow is obtained from river water flow or irrigation channel flow. If we use river water flow during the dry season, we will face dry river water flow and cause rice fields/gardens to fail to harvest. Then in the rainy season, the river water flow will be swift and cause rice fields/gardens to be submerged $[7,8,9,10]$. 
The current condition is the use of floodgates in irrigation channels. The problem that often arises is the irrigation officer negligent in opening or closing the irrigation door, causing the rice fields/gardens to be submerged or drought.

This research designed a prototype monitoring and control systems of irrigation. The working concept of this prototype is to measure the value of the soil acidity sensor, measure the value of the soil moisture sensor and measure the value of the water level sensor, which is then sent to Arduino nano and passed to Arduino Wemos. On Arduino Wemos, there will be an exchange of data to the webserver. The output of this prototype is to display information to the Screen of Android Smartphones and LCD. The Android-based application designed in this research has a function to monitor and control the status of irrigation floodgates that can be opened and closed through Android-based applications.

\section{METHOD}

Prior research is collecting journal reference data for research material for researchers to facilitate the research. The novelty in this research is to connect the control system and irrigation door monitoring system using the android smartphone feature using wireless sensor network method and connected in the internet network to generate a real time display and control automatically. Other features can monitor soil moisture value, soil acidity value, and groundwater level. the entire system can be displayed on Android smartphone screens, LCD screens, and website screens

\section{Research on Smart Irrigation: State of The Art}

Arduino is a microcontroller device containing hardware and software in the form of a physical computing platform that is open-source on an interactive and straightforward I/O board so that the output can detect and respond to situations in real conditions [11][12].

Monitoring and controlling the internet-based irrigation system uses water level sensors, soil moisture sensors and soil acidity sensors. The goal to be achieved that a result sensor output value that has been calibrated and displayed in an LCDs. However, this design also still uses LCDs as output outputs to monitor and control the irrigation system based on the internet of things. Table 1 shows the results of a literature review that focuses on controlling the irrigation system so that the output produced can run automatically and can be controlled using the Internet of Things method [13, 14, 15, 16, 17, 18, 19, 20, 21, 22].

Table 1. Research on smart irrigation: literature review

\section{Fazriati, Automatic Irrigation System Simulation in Rice Plants Using Arduino Module and GPRS}

\section{Module [13]}

Problem Conventional irrigation systems that are still found in Indonesia cause a lack of efficiency and effectiveness of farmers in controlling and monitoring irrigation systems on plants that they have planted to overcome this. This research is designed to design a system that can utilize science and technology that facilitates work for the farmers.

Method The proposed method is the design of an irrigation system based on: scheduling, weather forecasts, plant conditions, soil moisture, and plant height. And the output of the system will be connected to the Arduino microcontroller and connected to the internet network.

Result

The results of this research are the output data can display the results on the system website as monitoring for users, so users do not need to do a direct check. Specification

Sensor Architecture
Humidity and Temperature
Sensor

Microcontroller

Result

Model

Sensor

Arduino

Monitoring via internet-based

Design 


\begin{tabular}{|c|c|c|c|}
\hline \multicolumn{4}{|c|}{ Lubis, et al., Monitoring System of Rice Plant Growth Using Microcontroller Sensor [14] } \\
\hline Problem & $\begin{array}{l}\text { Rice is a type of pl } \\
\text { good rice yield is } \\
\text { conditions, water lev }\end{array}$ & $\begin{array}{l}\text { is spread in tropical and subtr } \\
\text { ined by several factors, incluc } \\
\text { moisture, and light intensity. }\end{array}$ & $\begin{array}{l}\text { gions. Get a } \\
\text { ntion to soil }\end{array}$ \\
\hline Method & $\begin{array}{l}\text { The method propose } \\
\text { supporting sensors } t \\
\text { level. }\end{array}$ & $\begin{array}{l}\text { s research is the use of Raspber } \\
\text { tor soil moisture, air humidity, }\end{array}$ & $\begin{array}{l}\text { duino and its } \\
\text { ensity, water }\end{array}$ \\
\hline Result & $\begin{array}{l}\text { The results of this } r \\
\text { soil moisture, air hur }\end{array}$ & $\begin{array}{l}\text { are successful monitoring of } \\
\text { light intensity and water level. }\end{array}$ & ts to monitor \\
\hline \multicolumn{4}{|c|}{ Specification } \\
\hline Sensor Architecture & Microcontroller & Result & Model \\
\hline $\begin{array}{l}\text { Soil Moisture Sensor, Air } \\
\text { Humidity Sensor, Light } \\
\text { Sensor, Water Level Sensor }\end{array}$ & $\begin{array}{l}\text { Arduino Nano, } \\
\text { Raspberry Pi }\end{array}$ & Monitoring via internet-based & Design \\
\hline
\end{tabular}

Kumar et al., (2017). Implementation of IoT in Smart Irrigation System Using Arduino Processor [15]

Problem The Internet of Things to irrigation systems is necessary to display all information received from various sensors and parameters given to Arduino as a microcontroller.

Method The method proposed in this research is the present value of the soil moisture sensor determined by the microcontroller to be a limiter.

Result

The result of this research is that this prototype successfully transmits information to the internet via the IoT network in the form of an installed ESP8266 Wi-Fi module. This results in an automatic irrigation system because the water pump can be turned on or off through information provided to the controller.

\begin{tabular}{|c|c|c|c|}
\hline \multicolumn{4}{|c|}{ ation } \\
\hline Sensor Architecture & Microcontroller & Result & Model \\
\hline $\begin{array}{l}\text { Soil Moisture, Humidity and } \\
\text { Temperature Sensor }\end{array}$ & Arduino & Monitoring via Wi-Fi ESP-8266 & Design \\
\hline \multicolumn{4}{|c|}{ Mutiara et al., Prototype of Control and Automation of Irrigation System for the Paddy Fields [16] } \\
\hline Problem & \multicolumn{3}{|c|}{$\begin{array}{l}\text { The problem in this research is the implementation of tangible forms of rice } \\
\text { fields to minimize the difficulties experienced by farmers and provide results of } \\
\text { monitoring rice field processing. }\end{array}$} \\
\hline Method & \multicolumn{3}{|c|}{$\begin{array}{l}\text { The proposed method is to design a water level automation system with SMS } \\
\text { notifications and scheduling automation for water exchange. }\end{array}$} \\
\hline Result & \multicolumn{3}{|c|}{$\begin{array}{l}\text { The results of this research are that the system succeeded in detecting the soil's } \\
\text { acidity with acidity sensors, controlling liquid fertilizer by sending an SMS and } \\
\text { providing output data on the LCD. }\end{array}$} \\
\hline \multicolumn{4}{|c|}{ Specification } \\
\hline Sensor Architecture & Microcontroller & Result & Model \\
\hline $\begin{array}{l}\text { Soil Moisture, Water Pump, } \\
\text { Humidity and Temperature } \\
\text { Sensor }\end{array}$ & Arduino & Monitoring via GSM (SMS) & Design \\
\hline \multicolumn{4}{|c|}{$\begin{array}{c}\text { Rahmat \& Hizriadi, Implementation of Real Time Monitoring of Agricultural Land in Rice Plants Using } \\
\text { Smart Sensors [17] }\end{array}$} \\
\hline Problem & \multicolumn{3}{|c|}{$\begin{array}{l}\text { The use of manual systems to determine the environmental conditions of rice } \\
\text { plants compared to the current control system is less efficient. Therefore, we } \\
\text { need a system that can monitor rice plants in real time. }\end{array}$} \\
\hline Method & \multicolumn{3}{|c|}{$\begin{array}{l}\text { The method proposed in this research is to monitor changes in air humidity, } \\
\text { temperature, soil acidity, soil moisture and light intensity. }\end{array}$} \\
\hline Result & \multicolumn{3}{|c|}{$\begin{array}{l}\text { The results of this research are the output of each sensor will be stored in a } \\
\text { database, and farmers will receive notification of monitoring of agricultural land } \\
\text { in the form of an SMS Gateway. }\end{array}$} \\
\hline \multicolumn{4}{|c|}{ Specification } \\
\hline Sensor Architecture & Microcontroller & Result & Model \\
\hline $\begin{array}{l}\text { pH Sensor, Humidity and } \\
\text { Temperature Sensor }\end{array}$ & Arduino & Monitoring via SMS & Design \\
\hline
\end{tabular}




\begin{tabular}{|c|c|}
\hline \multicolumn{2}{|c|}{ Rima, et al., Prototype Design of Soil pH Control Systems for Shallot Plants Using the E201-C Sensor [18] } \\
\hline Problem & $\begin{array}{l}\text { The prototype design of the soil acidity control system on onion plants using the } \\
\text { Arduino Uno microcontroller module and the E201-C sensor. The E201-C sensor } \\
\text { can detect soil acidity, and the output of the E201-C sensor will be processed in a } \\
\text { microcontroller which is then displayed on the LCD. }\end{array}$ \\
\hline Method & $\begin{array}{l}\text { The method proposed in this research is an on / off control system using two } \\
\text { relays at two mini water pumps. }\end{array}$ \\
\hline Result & $\begin{array}{l}\text { This research shows that the } 1 \text { st pump successfully drains the solution of the } \\
\text { Ketapang leaf and the other pump successfully flows the lime solution into a box } \\
\text { planted with shallots. }\end{array}$ \\
\hline \multicolumn{2}{|r|}{ Specification } \\
\hline Sensor Architecture & Microcontroller \\
\hline pH Sensor & Monitoring via LCD display \\
\hline \multicolumn{2}{|c|}{$\begin{array}{c}\text { Rosada, Ichsan, \& Setyawan, Irrigation System in Multi-Level Rice Fields Using Wireless Sensor Network } \\
{[19]}\end{array}$} \\
\hline Problem & $\begin{array}{l}\text { One significant factor in increasing agricultural production is the irrigation } \\
\text { system. Unfortunately, the irrigation system is a problem for every farmer who } \\
\text { cannot inspect and control the irrigation system. }\end{array}$ \\
\hline Method & $\begin{array}{l}\text { The method proposed in this research is WSN technology to control and inspect } \\
\text { irrigation systems. }\end{array}$ \\
\hline Result & $\begin{array}{l}\text { The result of this research is that this irrigation system has successfully } \\
\text { combined a wireless sensor network making it easier for farmers to check and } \\
\text { control the irrigation system }\end{array}$ \\
\hline \multicolumn{2}{|r|}{ Specification } \\
\hline Sensor Architecture & Microcontroller \\
\hline $\begin{array}{l}\text { Water Pump Sensor and } \\
\text { Water Level Sensor }\end{array}$ & Monitoring via Bluetooth \\
\hline \multicolumn{2}{|c|}{$\begin{array}{c}\text { Sugiono, Indriyani, \& Ruswiansari, Remote Control of Internet of Things (IoT) Based Rice Field } \\
\text { Irrigation Systems [20] }\end{array}$} \\
\hline Problem & $\begin{array}{l}\text { This research aims to design an irrigation control system using Wemos D1 } \\
\text { ESP8266 to irrigate fields remotely in real time aimed at increasing the } \\
\text { effectiveness of farmers' work and facilitating the work of farmers. }\end{array}$ \\
\hline Method & $\begin{array}{l}\text { The method proposed in this research is the use of an Android application that is } \\
\text { connected to the node controller via the APY key of web hosting. }\end{array}$ \\
\hline Result & $\begin{array}{l}\text { The results of this research are successful system testing with normal functional } \\
\text { connectivity }\end{array}$ \\
\hline \multicolumn{2}{|r|}{ Specification } \\
\hline Sensor Architecture & Microcontroller \\
\hline Water Level Sensor & $\begin{array}{l}\text { Monitoring via internet-based and } \\
\text { Android-based }\end{array}$ \\
\hline \multicolumn{2}{|c|}{$\begin{array}{c}\text { Raharja, Zamzami, Fransiska, \& Janardana, Smart Arduino Based Irrigation as Subak Water Control to } \\
\text { Maintain Food Security [21] }\end{array}$} \\
\hline Problem & $\begin{array}{l}\text { The problem that occurs in the irrigation system is opening and closing the } \\
\text { irrigation door to the paddy field not according to the time given by the } \\
\text { customary leader. Besides, during the dry season the water distribution is } \\
\text { sometimes uneven because water availability in the dam does not meet the needs. }\end{array}$ \\
\hline Method & $\begin{array}{l}\text { The method proposed in this research is to design Arduino-based smart irrigation } \\
\text { to facilitate the management of Subak water distribution. }\end{array}$ \\
\hline Result & $\begin{array}{l}\text { This research shows that this system successfully programmed the RTC module } \\
\text { and the monitoring system uses the GSM SIM900 module. }\end{array}$ \\
\hline \multicolumn{2}{|r|}{ Specification } \\
\hline Sensor Architecture & Microcontroller \\
\hline RTC & Simulation \\
\hline
\end{tabular}




\begin{tabular}{ll}
\hline Shekhar, Y., Dagur, E., Mishra, S., \& Sankaranarayanan, S. (2017). Intelligent IoT based automated \\
irrigation system [22]
\end{tabular}

\section{Material}

Android-based application tasked to open or close the irrigation door with a command script has been designed in the form of a pump button on and a pump button off. Figure 1 shows a flowchart of this system working. It starts from the reading of the water level sensor, soil moisture sensor and soil acidity sensor. Then the data is processed by a microcontroller. If the output is read, the output data will be sent to the database and displayed in an Androidbased application.

Figure 2 shows the results of a prototype assembled and equipped by Arduino Uno to read the values of the water level sensor, soil moisture sensor and acidity sensor. This prototype has been equipped with several supporting sensors, including water level sensors, soil moisture sensors, and soil acidity sensors. The output of these three sensors will be displayed to Android-based applications. The way this prototype works starts when the water level sensor detects the water level close to the ground $(<3 \mathrm{~cm})$, then the door of the irrigation flow will open, so the water runs through the prototype container. This prototype has been equipped with an Android-based application to monitor and control the rice field irrigation system. Arduino Wemos functions as a microcontroller sending data from Arduino nano to the server to display the output to an Android-based application.

Figure 3 shows a block diagram system with a 3-input sensor, including a soil moisture sensor that functions to detect soil moisture, an acidity sensor that detects acidity in the soil, and a water level sensor that measures water level above the ground. The Arduino Nano microcontroller will process the output of the three sensors until the output is sent to Arduino Wemos. Finally, a decision will be made to open the irrigation gate.

Figure 4 shows an Android-based application design that functions to carry out water level monitoring and control. In addition, this Android-based application has a statistical data feature in the form of a sensor output change table that has been adjusted to the data entered into the database. 


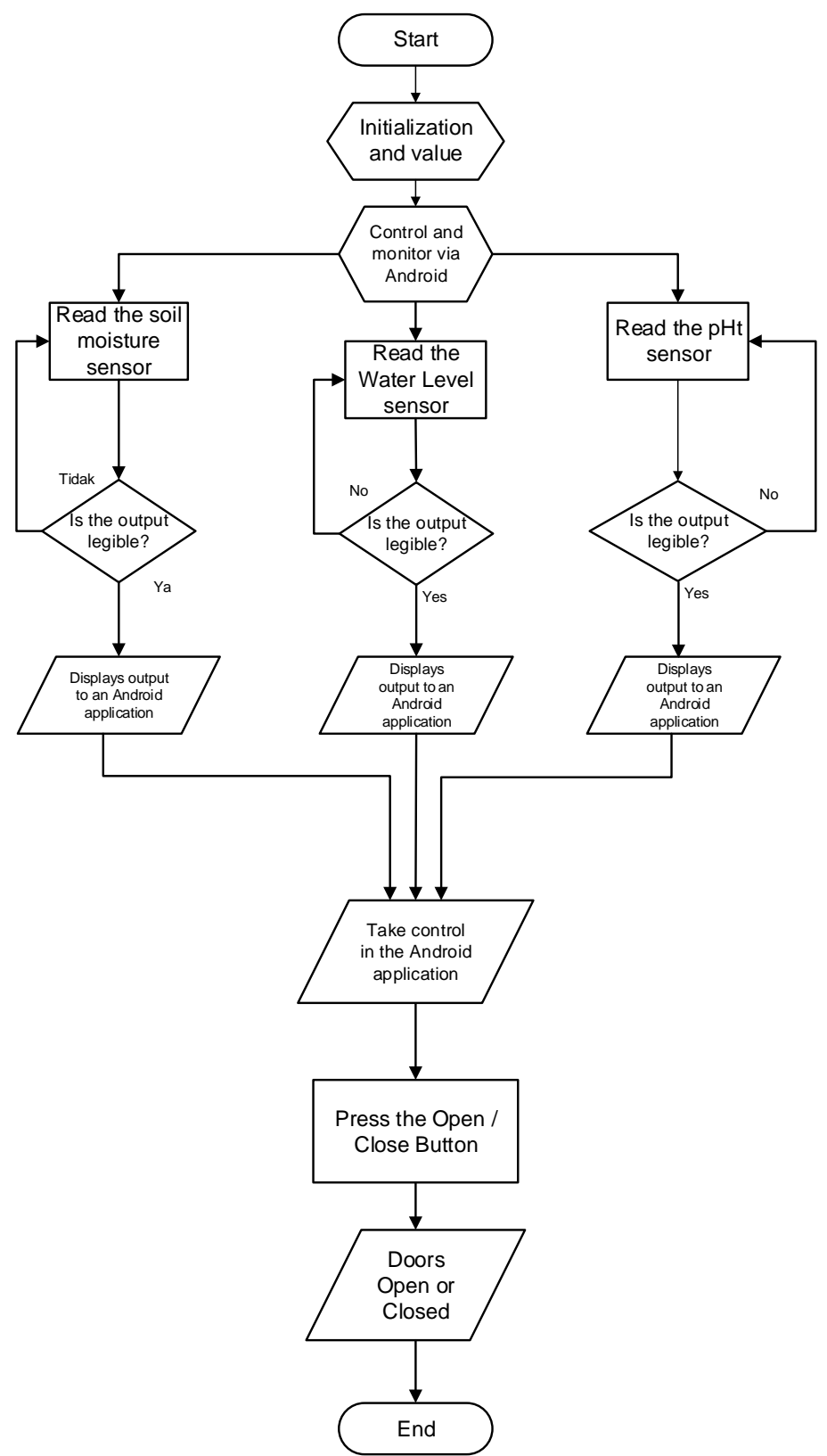

Figure 1. Flowchart of Research Design

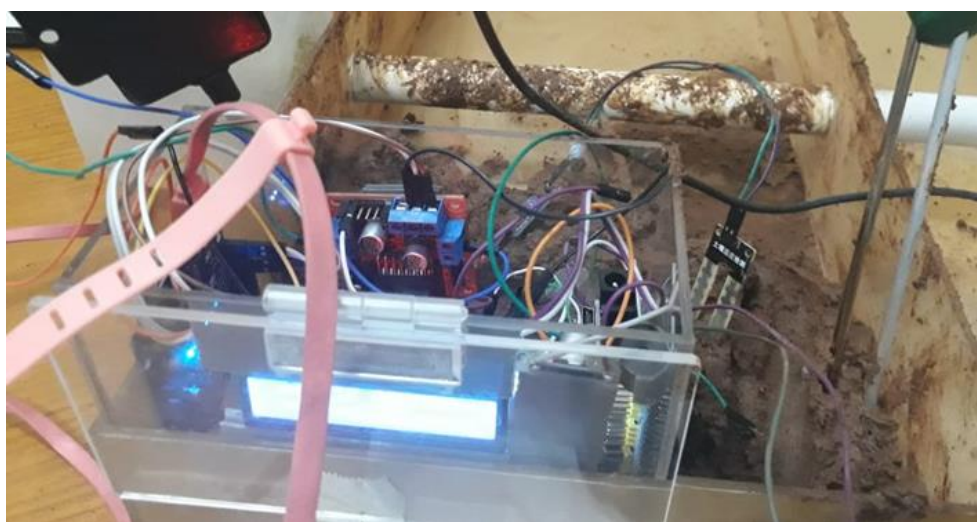

Figure 2. Prototype Overview 


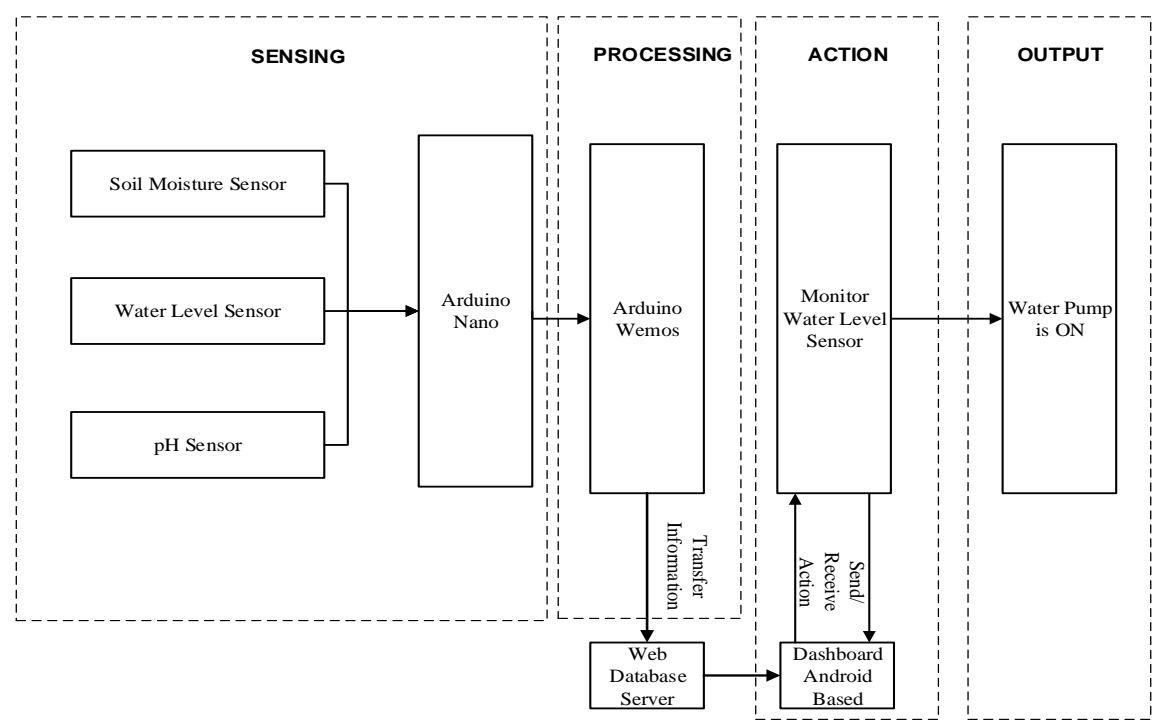

Figure 3. Block diagram

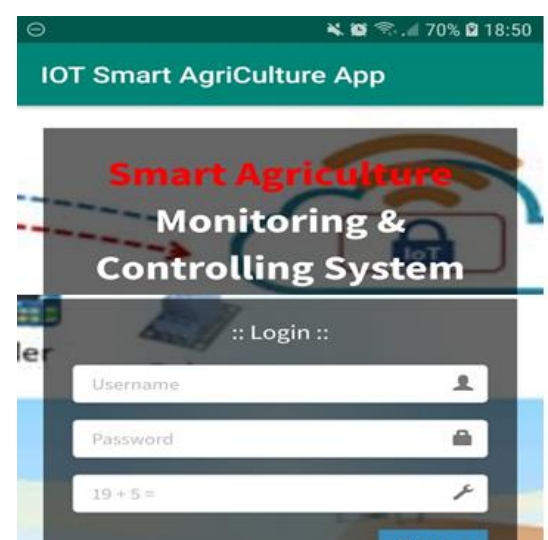

Figure 4. The interface of Android-based application

\section{RESULTS AND DISCUSSION Soil Moisture Sensor Testing}

Figure 5 shows the results of the calibration test for the accuracy of the soil moisture sensor. This sample aims to produce a precise and comparative output value between the soil moisture sensor embedded in the prototype and the Three-Way Meter.

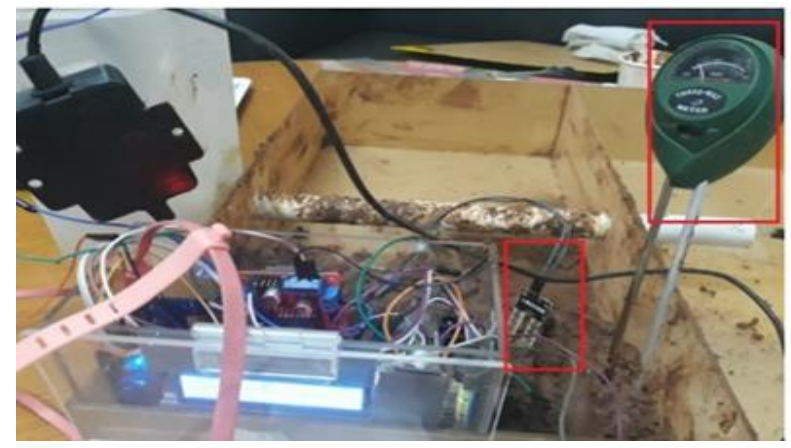

(a) Soil moisture testing

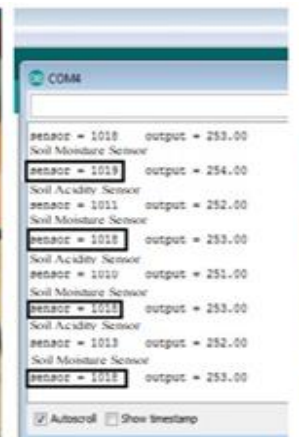

(b) Serial Monitor

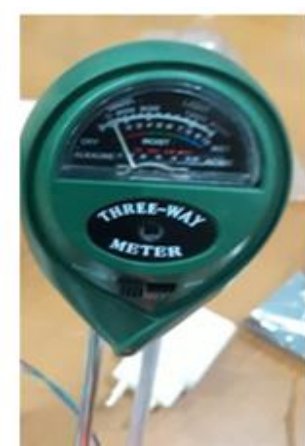

(c) Three-way Meter

Figure 5. Soil moisture testing 
Table 2 shows the comparison of the output of the soil moisture sensor with the ThreeWay Meter so that it produces dry or moist conditions.

Table 2. Soil moisture sensor testing

\begin{tabular}{ccc}
\hline Status & Soil Moisture Value & 3-Way Soil Meter \\
\hline Dry & 0.048 & 1 \\
Moist & 6.617 & 7 \\
\hline
\end{tabular}

In Table 2, it can be analyzed that the soil moisture sensor has been calibrated. The following conversion formula (Equation 1) is used for soil moisture values obtained from the serial monitor.

Calibration_of_soil_moisture $=\left[1-\frac{\text { Serial_data_monitor }_{-}}{\max \_v a l u e_{-} \text {of_soil_moisture_sensor }}\right] \times 10$

\section{Soil Acidity Sensor Testing}

Figure 6 shows the results of the calibration test for the accuracy of the soil acidity sensor. This sample aims to produce a precise and comparative output value between the acidity soil sensor that has been embedded in the prototype and the Three-Way Meter.

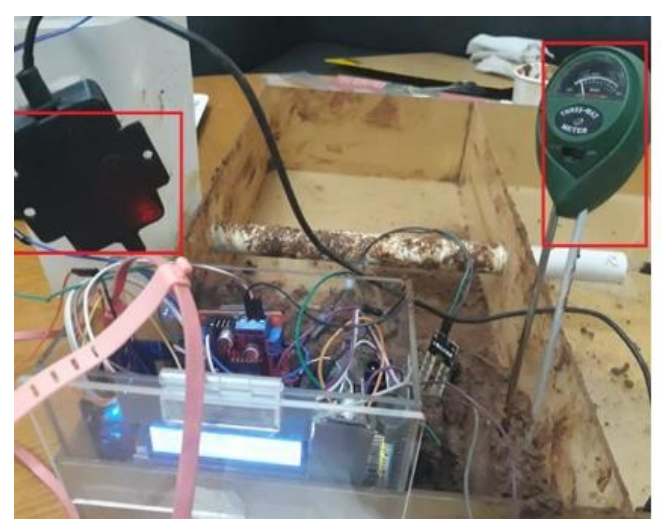

(a) Soil acidity testing

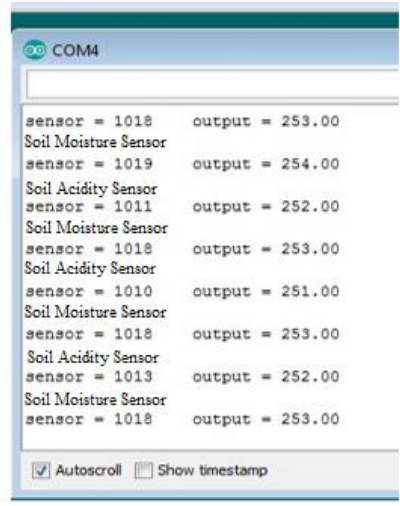

(b) Serial Monitor

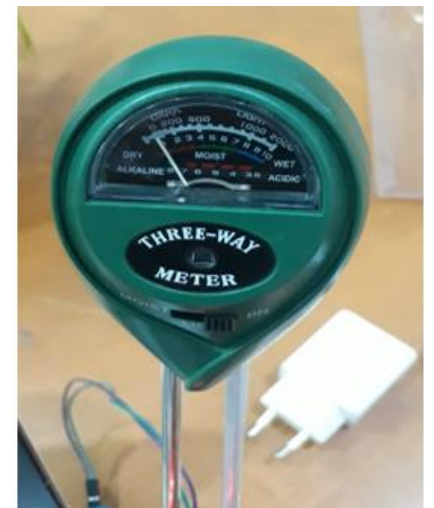

(c) Three-way Meter

Figure 6. Soil acidity testing

Table 3 shows the comparison of the outputs of the soil acidity sensor with the Three-Way Meter to produce acid or alkaline conditions.

Table 3. Soil acidity sensor testing

\begin{tabular}{ccc}
\hline Status & Soil Acidity Value & 3-Way Soil Meter \\
\hline Alkaline & 7.921 & 8 \\
Acid & 2.73 & 3 \\
\hline
\end{tabular}

In Table 3, it can be analyzed that the soil acidity sensor has been calibrated. The following conversion formula (Equation 2) is used for soil acidity values obtained from serial monitors.

Calibration_of_soil_acidity $=\left[\frac{\text { Serial_data_monitor }}{\max \_ \text {value_of_soil_moisture_sensor }}\right] \times 8$ 


\section{Water Level Sensor Testing}

Figure 7 shows the results of the calibration test for the accuracy of the water level sensor. This sample aims to produce a precise and comparative output value between the water level sensor that has been embedded in the prototype and a ruler.

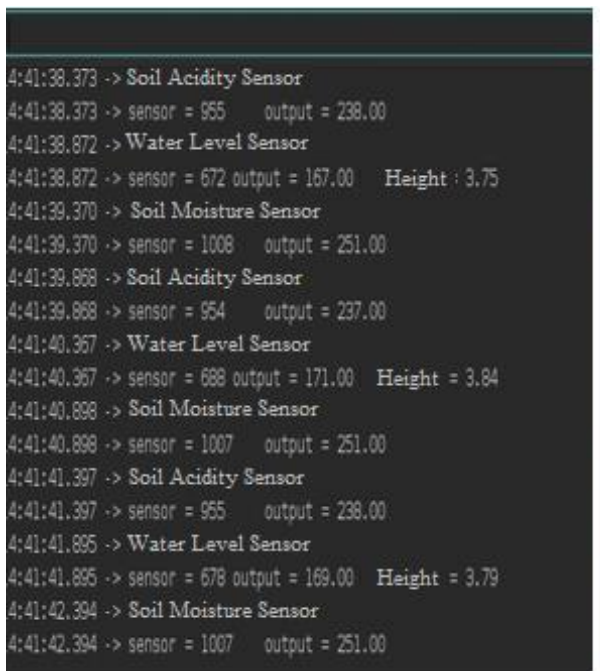

(a) Water level sensor testing via serial monitor

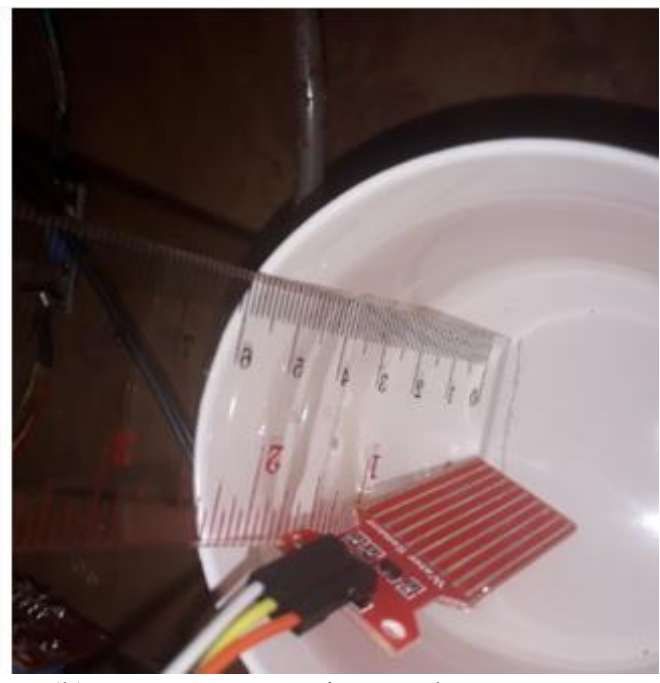

(b) Measurement using a ruler

Figure 7. Water level sensor sampling

Table 4 shows the comparison of the output of the ground level sensor with a ruler so that it produces water level above the ground. In Table 4, it can be analyzed that the water level sensor has been calibrated.

Table 4. Water level sensor sampling

\begin{tabular}{lcc}
\hline Status & Water Level Sensor $(\mathbf{c m})$ & Ruler $(\mathbf{c m})$ \\
\hline Experiment 1 & 3.75 & 3.7 \\
Experiment 2 & 3.84 & 3.9 \\
Experiment 3 & 3.79 & 3.8 \\
\hline
\end{tabular}

\section{Water Pump Testing}

In Table 5, it can be analyzed that the output voltage value when the water pump is on/off. In Table 5, it can be analyzed that the condition of the pump turns on when the voltage is 3.61 Volts and when it turns off at 1.29 Volts.

\begin{tabular}{cc}
\multicolumn{2}{c}{ Table 5. Water level sensor sampling } \\
\hline Pump Status & Output Voltages \\
\hline Pump On & 3.61 \\
Pump Off & 1.29 \\
\hline
\end{tabular}

\section{Internet-Based System Analysis of Things}

The things tested and analyzed from the designed prototype are divided into manual and automatic modes. The manual mode that has been tested and analyzed is opening/closing the irrigation door to turn the water pump on/off against the android application system created. The application can perform the command to turn off or turn on the pump in the "pump controlling" menu shown in Figure 8.

The auto mode that has been tested and analyzed that when the soil moisture sensor is above the 800 , then the irrigation door will open automatically. Conversely, if the sensor value is below 800, the irrigation door will automatically be closed, as shown in Figure 9. 


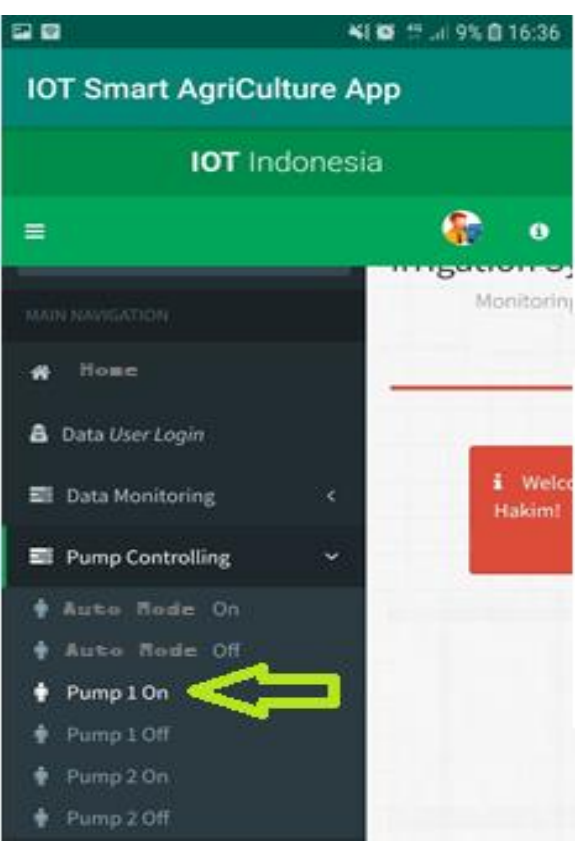

Figure 8. Manual mode

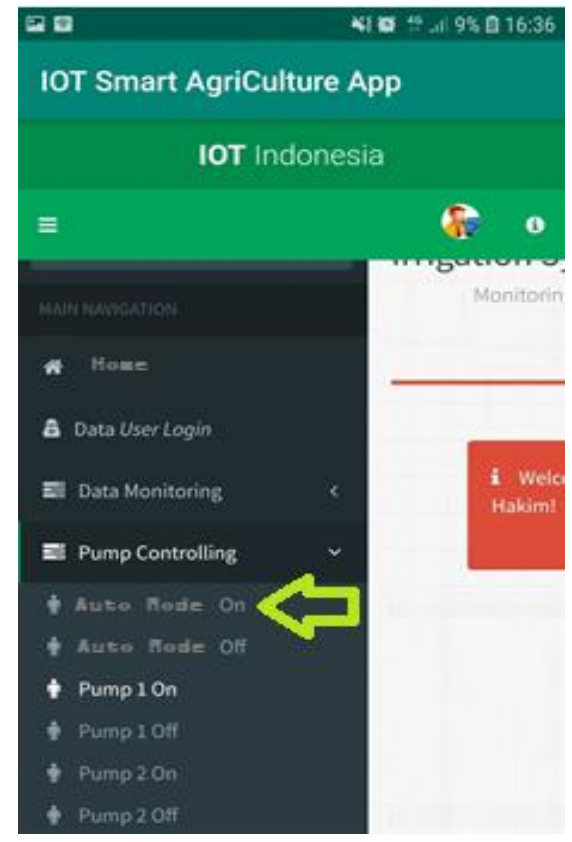

Figure 9. Auto mode

The next test was retrieving soil equality sensor values from the database on January 6, 2021, from 5:00 pm to 5:57 pm. This test shows the movement of the value change from the acidity sensor shown in Figure 10. The thing that can be analyzed is that the soil acidity sensor has successfully read the change in status from acidic condition to alkaline condition or vice versa.

Then the test conducted is the retrieval of soil moisture sensor values from the database on January 6, 2021, from 17:00 to 17:57. This test shows the movement of the value change from the soil moisture sensor shown in Figure 11. The thing that can be analyzed is that the soil moisture sensor has successfully read the status change from dry, humid and wet conditions.

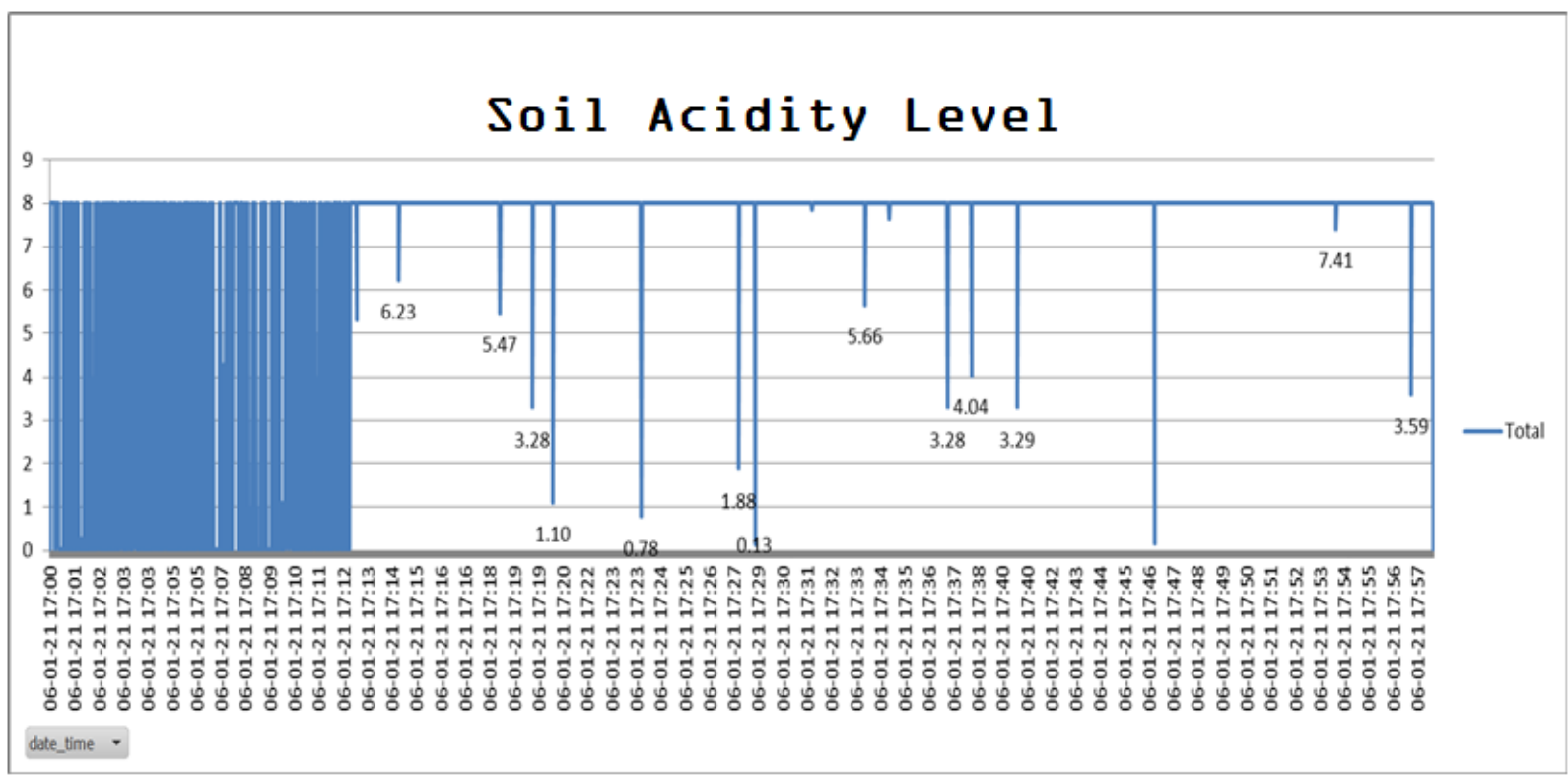

Figure 10. Soil acidity level 


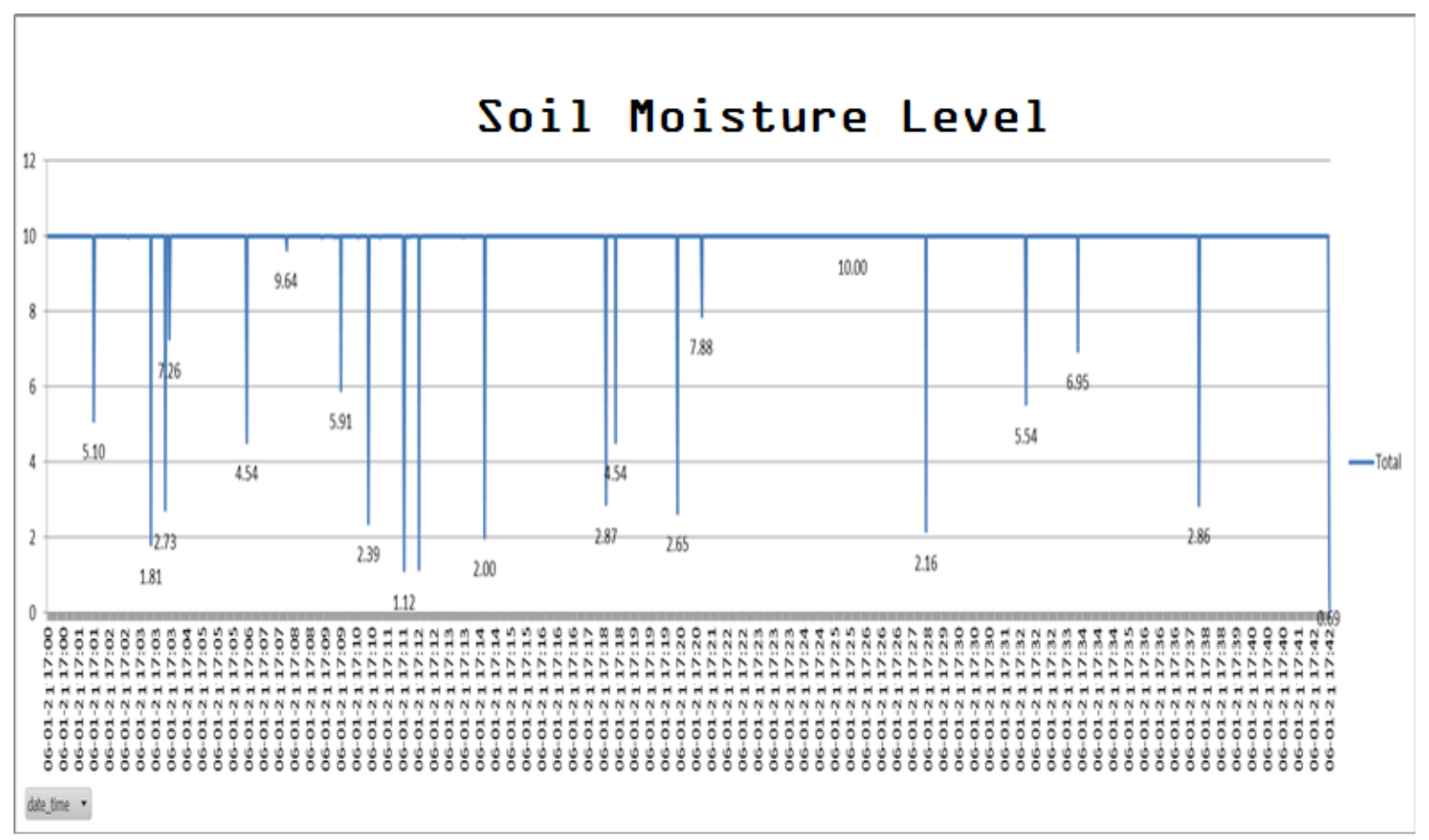

Figure 11. Soil moisture level

\section{CONCLUSION}

Based on the results of experiments that have been carried out, there are some conclusions. The first is the design of a monitoring and controlling system for irrigation of rice fields connected with Android was successfully made. The system can send sensor value data to the database which is forwarded to the application every 5 seconds. The second is the application's design, which serves to provide information and status of the sensor value is successfully made. For acid levels at levels 7 through 2, for alkaline levels at level 8, for dry levels at levels 1 through 3, for humid levels at levels 4 through 7, for wet levels at levels 8 through 10. At the time of the pump, work 3.61 volts, when the pump is not working 1.29 volts. The third is based on the results of the analysis and testing that have been carried out in this research, and the irrigation door will open when the soil is dry, marked with a value of less than $3 \mathrm{~cm}$ water level and control through the application.

\section{ACKNOWLEDGMENT}

The special thanks to Mercu Buana University, which has supported research and the second to partner research for his/her assistance and cooperation during this research.

\section{REFERENCES}

[1] Gagandeep, D. Arora and H. S. Saini, "Design and implementation of an automatic irrigation feedback control system based on monitoring of soil moisture," 2017 International Conference on Inventive Computing and Informatics (ICICI), 2017, pp. 540-544, doi: 10.1109/ICICI.2017.8365190

[2] N. Ismail, S. Rajendran, W. C. Tak, T. Xin, N. Anuar, et al., "Smart irrigation system based on internet of things (IOT)," In Journal of Physics: Conference Series, vol. 1339, no. 1, pp. 012012, December 2019, doi: 10.1088/1742-6596/1339/1/012012

[3] S. R. Vukelich and J. Jenkins, "Evaluation of component buildup methods for missile aerodynamic prediction," Journal of Spacecraft and Rockets, vol. 19, no. 6, pp. 481-488, 1982, doi: 10.2514/3.62290

[4] N. Liundi, A. W. Darma, R. Gunarso and H. L. H. S. Warnars, "Improving Rice Productivity in Indonesia with Artificial Intelligence," 2019 7th International Conference on Cyber and IT Service Management (CITSM), 2019, pp. 1-5, doi: 10.1109/CITSM47753.2019.8965385. 
[5] A. N. Afif, F. Noviyanto, S. Sunardi, S. A. Akbar, \& E. Aribowo, "Integrated application for automatic schedule-based distribution and monitoring of irrigation by applying the waterfall model process," Bulletin of Electrical Engineering and Informatics, vol. 9, no. 1, pp. 420-426, 2020, doi: 10.11591/ eei.v9i1.1368

[6] F. Kurniawan, H. Nurhayati, Y. M. Arif, S. Harini, S. M. S. Nugroho and M. Hariadi, "Smart Monitoring Agriculture Based on Internet of Things," 2018 2nd East Indonesia Conference on Computer and Information Technology (EIConCIT), 2018, pp. 363-366, doi: 10.1109/EIConCIT.2018.8878510

[7] K. H. Kamaludin and W. Ismail, "Water quality monitoring with internet of things (IoT)," 2017 IEEE Conference on Systems, Process and Control (ICSPC), 2017, pp. 18-23, doi: 10.1109/SPC.2017.8313015

[8] S. B. Saraf and D. H. Gawali, "IoT based smart irrigation monitoring and controlling system," 2017 2nd IEEE International Conference on Recent Trends in Electronics, Information \& Communication Technology (RTEICT), 2017, pp. 815-819, doi: 10.1109/RTEICT.2017.8256711

[9] B. Pratama, S. Sfenrianto, A. N. Fajar, A. Amyus and R. Nurbadi, "A Smart Agriculture Systems Based on Service Oriented Architecture," 2018 3rd International Conference on Information Technology, Information System and Electrical Engineering (ICITISEE), 2018, pp. 281-286, doi: 10.1109/ICITISEE.2018.8720989.

[10] F. Rozie, I. Syarif and M. U. H. Al Rasyid, "Design and implementation of Intelligent Aquaponics Monitoring System based on IoT," 2020 International Electronics Symposium (IES), 2020, pp. 534-540, doi: 10.1109/IES50839.2020.9231928.

[11] S. Budiyanto, L. M. Silalahi, F. A. Silaban, K. S. Salamah, F. Rahayu, M. I. Wahyuddin, \& S. Andryana, "Design of control and monitoring tools for electricity use loads, and home security systems with internet of things system based on Arduino Mega 2560," In IOP Conference Series: Materials Science and Engineering, vol. 909, no. 1, pp. 012020, 2020, doi: 10.1088/1757-899X/909/1/012020

[12] M H. I. Hajar, A. W. Dani \& S. Miharno, "Monitoring of electrical system using internet of things with smart current electric sensors," SINERGI, vol. 22, no. 3, pp. 211-218, 2018, doi: 10.22441/sinergi. 2018.3.010

[13] C. J. H. Pornillos et al., "Smart Irrigation Control System Using Wireless Sensor Network Via Internetof-Things," 2020 IEEE 12th International Conference on Humanoid, Nanotechnology, Information Technology, Communication and Control, Environment, and Management (HNICEM), 2020, pp. 1-6, doi: 10.1109/HNICEM51456.2020.9399995.

[14] H. Lubis, R. F. Rahmat, J. Karansa, \& S. Purnamawati, "Monitoring System of Rice Plant Growth Using Microcontroller Sensor," In Journal of Physics: Conference Series, vol. 1235, no. 1, pp. 012116, 2019, doi: 10.1088/1742-6596/1235/1/012116

[15] N. Kabilan and M. S. Selvi, "Surveillance and steering of irrigation system in cloud using Wireless Sensor Network and Wi-Fi module," 2016 International Conference on Recent Trends in Information Technology (ICRTIT), 2016, pp. 1-5, doi: 10.1109/ICRTIT.2016.7569526.

[16] G. A. Mutiara, G. I. Hapsari, and D. J. Kusumo, "Prototype of Control and Automation of Irrigation System for the Paddy Fields," Advanced Science Letters, vol. 23, no. 5, pp. 4036-4040, 2017, doi: doi.org/10.1166/asl.2017.8281

[17] R. F. Rahmat, T. Z. Lini, Pujiarti and A. Hizriadi, "Implementation of Real-Time Monitoring on Agricultural Land of Rice Plants Using Smart Sensor," 2019 3rd International Conference on Electrical, Telecommunication and Computer Engineering (ELTICOM), 2019, pp. 40-43, doi: 10.1109/ELTICOM47379.2019.8943912.

[18] R. D. Rima, W. Wildian, and N. Firmawati, "Prototype Design of Soil pH Control Systems for Shallot Plants Using the E201-C Sensor," Jurnal Fisika Unand, vol. 7, no. 1, pp. 63-68, 2018, doi: 10.25077/jfu.1.63-68.2018

[19] A. Rosada, M. H. H. Ichsan, and G. E. Setyawan, "Irrigation System in Multi-Level Rice Fields Using Wireless Sensor Network," Jurnal Pengembangan Teknologi Informasi dan Ilmu Komputer, vol. 3, no. 4, pp. 3971-3977, Februarry 2019

[20] S. Sugiono, T. Indriyani, and M. Ruswiansari, "Remote Control of Internet Based Things (IoT) Rice Field Irrigation Systems," INTEGER: Journal of Information Technology, vol. 2, no. 2, pp. 41-48, 2017, doi: 10.31284/j.integer.2017.v2i2.178

[21] R. Madushanki, H. Wirasagoda, \& M. Halgamuge, "Adoption of the Internet of Things (IoT) in agriculture and smart farming towards urban greening: A review," doi: 10.14569/IJACSA.2019.0100402

[22] Y. Shekhar, E. Dagur, S. Mishra, and S. Sankaranarayanan," Intelligent IoT based automated irrigation system," International Journal of Applied Engineering Research, vol. 12, no. 18, pp. 7306-7320, 2017 